\title{
W. B. Yeats (1865-1939)
}

\section{The Second Coming}

Turning and turning in the widening gyre The falcon cannot hear the falconer; Things fall apart; the centre cannot hold; Mere anarchy is loosed upon the world, The blood-dimmed tide is loosed, and everywhere The ceremony of innocence is drowned; The best lack conviction, while the worst Are full of passionate intensity.

Surely some revelation is at hand;

Surely the Second Coming is at hand.

The Second Coming! Hardly are those words out When a vast image out of Spiritus Mundi Troubles my sight: somewhere in sands of the desert A shape with lion body and the head of a man, A gaze blank and pitiless as the sun, Is moving its slow thighs, while all about it Reel shadows of the indignant desert birds. The darkness drops again; but now I know That twenty centuries of stony sleep Were vexed to nightmare by a rocking cradle, And what rough beast, its hour come round at last, Slouches towards Bethlehem to be born? 


\section{Translated by Francisco Javier Torres Ribelles}

\section{El Segundo Adviento}

Girando y girando en el remolino creciente, el halcón no oye al halconero; todo se derrumba, el centro no aguanta; mera anarquía libre por el mundo, la ola negra de sangre, y por doquier se ahoga la ceremonia de inocencia; los mejores no tienen convicción, los peores rebosan gran pasión.

Sin duda una revelación se acerca; sin duda el Segundo Adviento se acerca. ¡El Segundo Adviento! Apenas dicho esto, del Spiritus Mundi, inmensa imagen turba mi vista: en arenas desiertas, con cuerpo de león y cabeza de hombre, mirada vacía y cruel como el sol, mueve sus lentos muslos, y en torno a ella sombras de airadas aves del desierto. La oscuridad cae otra vez; y ahora sé que veinte siglos de pétreo dormir fueron mal sueño al mecer una cuna. ¿Qué bestia brutal, llegada al fin su hora, se arrastra hacia Belén para nacer? 